possibility of a joint select committee of both Houses. While the Government agrees entirely that the terms of reference of the proposed committee should not enter into questions of detailed administration, it does not agree with the proposal that the committee should inquire into future plans and programmes as suggested in the report. To commence with, the Government thinks that the committee should not exceed ten to fourteen members, and that it would be a mistake to provide the committee with a permanent officer of the House, such as the Comptroller and Auditor General. It prefers the alternative suggestion of beginning with a clerk from the committee office and with someone of the nature of a Treasury liaison officer. If an independent officer is then found to be required, the matter could be considered by Parlia. ment. Tentatively, Mr. Crookshank suggested that it would be much wiser not to publish all the evidence but merely reports from time to time, and it is not thought that every industry should come, in some form or other, before the select committee each year. It should be made clear that the constitution of the committee should not touch in any way the existing rights of ministers under legislation.

\section{Auditing of Non-Recurrent Grants to British Universities}

IN a Special Report from the Committee of Public Accounts (Session 1953-54 : Treasury Minute and Abstract of Appropriation Accounts, 67. London : H.M.S.O., 1954; $1 s$. net) the Treasury refers to the recommendation of the Committee, in its third report for session 1952-53, that the books and accounts of the universities of Great Britain relating to their expenditure of non-recurrent grants should be open to inspection by the Comptroller and Auditor General. The Treasury reiterates that it has no reason for thinking that the sums voted have not been wisely administered. The essence of the relations between the universities and the Government has been that the Treasury should avoid any detailed control of the activities of universities. Neither the Treasury nor the University Grants Committee has ever claimed the right to examine the universities' books, and the Treasury believes that to do so in the way suggested by the Committee would lead to increased intervention and extended control in a way which would prejudice the present harmonious relation between the universities and the University Grants Committee. 'The Treasury, however, foresees no difficulty in making satisfactory arrangements with the universities which would enable the Public Accounts Committee to satisfy itself that the grants are duly appropriated to meet the expenditure for which they are made, though the precise part to bé played by the universities' auditors and professional advisers will require consideration. With regard to the more important question of ensuring economy in the expenditure of non-recurrent grants, the Treasury is considering whether the assurances desired could be obtained by some other means ; thus the University Grants Committee might appoint one or more persons to report to it on any changes necessary to ensure that the methods adopted by the universities for contracting and recording and controlling expenditure are reasonably designed, and properly applied, to provide effective safeguards against waste, extravagance or other abuse. Such a report would be made available to the Public Accounts Committee with a note of any action taken or proposed. "The
Treasury proposes to discuss this matter with the university authorities.

\section{Co-ordination of Research in Scotland}

IN reply to a question to the Secretary of State for Scotland, on February 2, referring to co-ordination between government, industrial and university laboratories for pooling the results of their scientific and technological research work, Mr. J. Stuart stated there is free exchange of research information between the universities, industrial research associations and the Department of Scientific and Industrial Research. That Department operates a technical information service available to large and small firms alike, and the research associations provide industrial liaison services to their member firms. The Department is arranging with the Scottish Office for a study of the special needs of small firms in Scotland for research and technical information.

\section{Absenteeism of Workers in Small and Large Organ- izations}

UNDER the title "Size and Morale : Preliminary Study of Attendance at Work in Large and Small Units" (pp. 44 ; London: Acton Society Trust, $1953 ; 3 s .6 d$.$) , the Acton Society Trust has issued a$ report covering three inquiries: one in the coal industry, one in a large industrial group and one in a large retail organization controlling 230 stores throughout Great Britain. All three inquiries showed that, as a general rule, workers are absent from work for one reason or another more frequently in large concerns than in small ones. The trend is particularly noticeable in the coal industry; it is fairly marked in the industrial sample, and just discernible in the commercial undertakings that were studied. The investigation showed that miners in the smaller pits appeared to take much more interest in the affairs of their own pit than did men working in larger pits. Further, absenteeism and accident-rates were statistically correlated with size throughout the coal industry, and, when similar geological conditions were being worked, output per man-shift tended to be higher in small pits than in large. It is not suggested that workers' morale is necessarily worse in large than in small units : the study emphasizes that there is an urgent need for detailed descriptive studies of individual working organizations if the significance of size is to be understood fully, and that investigations into the social and human factors are likely to provide the most saluable clues. Studies of the social effect on absenteeism of the distance of travel of the worker to his place of employment and of the effect of the number of hierarchical stages in the line of communication between the employee and the local manager are suggested as promising lines of inquiry.

\section{Trends in Trade Union Organization}

Is 1894, the year when the Webbs published their first edition of the "History of Trade Unionism", the Labour Department of the Board of Trade recorded 1,314 trade unions with a total membership of $1,530,000$. By the end of 1951 the number of unions had fallen to 704 and the total membership had reached $9,480,000$. In 1894 the average number of mombers per union was 1,160 , whereas in 1951 it was 13,452, a twelvefold increase. These broad statistical changes clearly indicate that trade unions have grown larger; but what they do not reveal is the degree to which union membership is concen- 